\author{
LAKOS Katalin \\ lakoskatalin@gmail.com \\ doktorjelölt (SZTE BTK)
}

\title{
Mikor élt a Buddha?
}

Kérdések és lehetséges válaszok

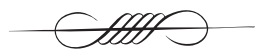

\section{- When Did Buddha Live? Questions and Possible Answers -}

Abstract There are three basic dating schemes for the determination of Buddha's historical dates: (1) "the long chronology", (2) the "corrected long chronology", and (3) the "short chronology". This article analyses the three traditional theories. Each of the theories has some persuasive arguments, yet each has serious problems. Which, if any, should we believe and how could one of them affirm any conclusion?

It was this dilemma that framed Heinz Bechert's symposium in Hedemünden near Göttingen between the $11^{\text {th }}$ and the $18^{\text {th }}$ of April, 1988. The only way to determine the dates of Buddha's life seems to be the examination of indirect evidences, the analysis of economic and cultural milieu in which Buddha's religious movement started and the consideration of the archaeological evidence. However, the available sources do not allow an exact reconstruction of the date of Buddha, because there is no convincing evidence whatsoever of reliable chronological information preserved in India before Alexander's campaign. Therefore the dating of the historical Buddha is still an open question.

Keywords Buddha, biography, chronology

DOI 10.14232/belv.2015.4.8 http://dx.doi.org/10.14232/belv.2015.4.8

Cikkre való hivatkozás / How to cite this article: Lakos Katalin (2015): Mikor élt a Buddha? Kérdések és lehetséges válaszok. Belvedere Meridionale 27. évf. 4. sz. 111-122. pp

ISSN 1419-0222 (print) ISSN 2064-5929 (online, pdf)

(Creative Commons) Nevezd meg! - Így add tovább! 4.0 (CC BY-SA 4.0)

(Creative Commons) Attribution-ShareAlike 4.0 International (CC BY-SA 4.0) 


\section{A Buddha-datálás fontossága, a kérdés aktualitása}

Sákjamuni Buddha halálának, vagyis maháparinirvánajának ${ }^{1}$ pontos dátuma a korai indiai történelem kulcsfontosságú dátuma, amely hosszú időn keresztül a legkorábbi, többé-kevésbé pontosan rögzített kronológiai adatnak számított az ókori indiai kronológiában.

Buddha életének pontos datálása nagy jelentőséggel bír többek között olyan nagy jelentőségủ ókori indiai királyok, mint a magadhai Bimbiszára, a kószalai Praszénadzsit uralkodási dátumának meghatározásában, Mahávíra datálásában, a dzsainizmus korai történetének megrajzolásában, a bráhmanizmus korai történetében, valamint a korábbi indiai filozófiai iskolák és irányzatok, beleértve az upanisadok felfogásának megértésében.

Buddha datálásával kapcsolatban sokáig egyetértés mutatkozott a kutatók körében. A legelfogadottabb álláspont szerint - ami a 19. századtól egészen napjainkig megtalálható a nyugati és a délkelet-ázsiai szakértők írásaiban - Buddha i. e. 480 körül halt meg. Ez a kronológiai számítás azon a buddhista hagyományon alapul, amely részben a ceyloni szerzők által az i. u. 4. és 6. században Ceylon szigetén (ma: Srí Lankán) szerkesztett páli krónikákat, részben pedig a Buddhaghósa által az i. u. 5. században szerkesztett Szamantapászádikát veszi alapul. Ugyanakkor ugyanezen forrásokra hivatkozva a ceyloni, valamint a délkelet-ázsiai théraváda buddhisták azt állítják, hogy Buddha fizikai halála nem i. e. 480 körül, hanem i. e. 544/543ban következett be. Ez az eredeti, ún. „nem javított hosszú" vagy más néven „déli buddhista kronológia", amely ma is használatos valamennyi théraváda közösségben Dél-és Délkelet-Ázsiában, míg az i. e. 480-nal kezdődő az ún. „javított ceyloni hosszú” kronológia.

\footnotetext{
1 „Végső, nagy kialvás” egyben Buddha fizikai halála.
}

\section{Kutatástörténeti áttekintés}

Az európai buddhista kutatás kezdeti szakaszában, a 19. század elején a kutatók a nem „javított hosszú kronológiát" használták egészen 1837-ig, a Mahávansza angol nyelvü fordításának megjelenéséig. ${ }^{2}$ Turnour munkája bevezetőjében többek között arra hívja fel a figyelmet, hogy 60 éves eltérés van Csandragupta Maurja uralkodási éveit illetően, a ceyloni hagyományban és a görög forrásokban megőrzött datálás között. Tehát arra a megállapításra jutott, hogy Csandragupta és Asóka király uralkodási évei hibásan szerepelnek a ceyloni krónikában, a krónika ugyanis túl koraira helyezte a királyok uralkodási éveit. Ugyanakkor elfogadta azt a kronológiai adatot, mely szerint 168 év telt el Buddha halála és Csandragupta trónra lépése és 218 év telt el Buddha halála és Asóka megkoronzása között. Turnour ezzel megalkotta az ún. „javított hosszú kronológiát". ${ }^{3}$ Asóka datálását aztán alátámasztotta a megfejtett Asóka-rendelet ${ }^{4}$ és a rendeleten említett kortárs görög uralkodók beazonosítása.

Bühler 1877-ben fogalmazta meg tézisét. ${ }^{5}$ Vitatott olvasata szerint Asóka a több nyelven is fennmaradt ún. első kis sziklarendeletében ${ }^{6}$ megadta a Buddha halála és a saját megkoronázása között eltelt időt, ami megerősíti a Buddha-datálással kapcsolatos ún. „javított hosszú kronológiát". Ezzel egy, a mai napig is tartó, ellentmondásokkal teli tudományos vita vette kezdetét.

Már a 19. században felmerültek olyan javaslatok, amelyek Buddha halálát jóval ké-

2 Turnour 1837.

3 Turnour 1837. 48-50.

4 Asóka XIII. sziklarendeletéröl van szó.

5 BüHLER 1877. 149-160.

${ }^{6}$ Pontosan az I. kis sziklarendeletről (Minor Rock Edict I.=MRE I.) van szó. Mivel a rúpnáthi (KözépIndia) maradt fenn a legjobb állapotban, ezért szokás ezt rúpnáthi rendeletnek is nevezni, de mindenképpen ezt a verziót szokták alapul venni a fordítások során. 
sőbbre helyezték. Ezeknek az elméleteknek a hatására a Buddha-datálás körüli tudományos vita a 19. század utolsó három évében és a 20. század első három évtizedében megélénkült. Speyer többek között az ún. „hosszú kronológiával" kapcsolatos hiba eredetére hívja fel a figyelmet, ${ }^{7}$ míg Hultzsch már egyenesen cáfolja a „hosszú kronológiát” 1913-ban megjelent tanulmányában. ${ }^{8}$

A 20. század harmincas éveitől kezdve a Buddha-datálással kapcsolatos viták egy időre nyugvópontra jutottak. 1946-ban a tudományos vita újra erőre kapott és az ezt követő évek legfontosabb munkái elsősorban ceyloni kutatók körében születnek. Mendis elutasítja mind a „nem javított hosszú”, mind pedig a „javított ceyloni hosszú kronológiát” és helyette az i. e. 365 körüli időpontot javasolja Buddha halálának. ${ }^{9}$ Barua 1947-ben megjelent összefoglaló tanulmányában pedig az ún. „javított hosszú kronológia" mellett érvel. ${ }^{10}$

Ezt követően, kevés kivétel mellett, mindenütt, a Nyugaton és a Délkelet-Ázsiában megjelent, az indiai történelemmel kapcsolatos modern kézikönyvekben, világtörténeti lexikonokban, vallási témájú munkákban is ezzel az ún. „javított hosszú kronológiával” találkozhatunk. Úgy tünt tehát, hogy az indiai történelemben Buddha kora viszonylag pontosan meghatározott dátumhoz köthető korszak. Persze továbbra is voltak olyan jelentős kutatók, akik inkább az ún. „nem javított hosszú kronológia” mellett érveltek. Ezek közé tartozott többek között Vincent A. Smith. ${ }^{11}$

Ennek ellenére egyre inkább úgy tünt, hogy a Buddha korára és az ezzel szorosan összefüggő korai indiai történelmi kronológiára vonatkozó „communis opinio” nem tartható fenn. Ebben közrejátszhatott az is,

7 SPeyer 1899. (1992.) 422-426.

8 Hultzsch 1913. (1992.) 430-444.

9 Mendis 1947. (1992). 445-460.

10 Barua 1947. (1992.) 461-467.

11 A szerző többek között a több kiadást megért The Early History of India címü nagy hatású munka szerzője. hogy a buddhista hagyomány fontos részét képezö, korai szanszkrit nyelvü buddhista munkák, amelyek a théraváda forrásoktól eltérő kronológiai hagyományt örökítettek meg, hangsúlyosabban kerültek be a kutatásba. Ezek a munkák az ún. „rövid kronológiát” használják, amely szerint Buddha halála és Asóka megkoronázása között mindössze csak 100 év telt el. Amint láthatjuk, a két hosszú kronológia leginkább a théraváda hagyománnyal, míg a rövid kronológia részben a szarvásztiváda és a mahájána hagyománnyal mutat összefüggést.

A Buddha-datálás kérdésében kulcsfontosságú szerepe lehet annak, hogy Asóka megkoronázására pontosan mikor került sor. Számos buddhista forrás ugyanis azt adja meg, hogy Asókát Buddha halála után hány évvel koronázták meg. Ennek megfelelően tehát, míg a rövid kronológiával fémjelzett buddhista hagyomány, a szanszkrit nyelvü buddhista források és ezek kínai és tibeti nyelvü forrásai Buddha halálát 100 évvel Asóka királlyá koronázása elé helyezik, addig az ún. „hosszú kronológiát" képviselő, elsősorban páli nyelvű buddhista források 218 évvel számolnak. Amint látjuk, az eltérés több, mint 100 év a két buddhista hagyomány között.

\section{A hedemündeni konferencia a Buddha datálásáról}

1982-ben jelent meg Bechert nevezetes tanulmánya, amelyben a szerző nyomós bizonyítékkal és hathatós érveléssel a rövid kronológia mellett tört lándzsát. ${ }^{12} \mathrm{Az}$ ezt követő döntő fontosságú esemény az 1988. április 11-18-a között a göttingeni egyetem rendezésében, a Göttingen melletti Hedemündenben sorra került szimpózium volt a kor legkíválóbb szakembereinek a részvételével. A szimpózium címe, „A történeti Buddha dátuma és meghatározásának fontossága az indiai histográfia és a világtörténet számára" önmagában is so12 BeChert 1982. 29-36. 
katmondó. Az ott elhangzott elöadásokból egy háromrészes konferenciakötet is készült, ${ }^{13}$ és a következő években számos publikáció látott napvilágot Európában, Indiában, Japánban és az Amerikai Egyesült Államokban ugyanebben a témában.

Az első kötet elején olvashatjuk Bechert angol nyelvü bevezetőjét, amelyben a szerző felvázolja a problémát, valamint a szimpóziumon elért eredményeket. ${ }^{14}$ A harmadik kötetben pedig egy német nyelvü összefoglalót nyújt a Buddha-datálás állásáról nyolc évvel a szimpózium eltelte után. ${ }^{15}$

A konferencia fó témája elsősorban a Buddha-datálás kérdése és problémája volt, kronológiai és történeti értelemben egyaránt. Az előadások egyik kulcsfontosságú kérdése az volt, hogy maga a buddhista hagyomány hogyan és miként kezelte a nirvána dátumát, valamint Buddha életének más, fontos eseményeit, így születését, megvilágosodását és tanító tevékenységének állomásait.

A három konferenciakötetben az egyes részekhez írt részletes bevezető mellett összesen mintegy ötven tanulmány található, amelyek különböző témakörök szerint lettek elosztva. ${ }^{16}$

13 BECHERT 1991-1992-1997.

14 BeChert 1991. 1-21.

15 BeChert 1997. 1-13.

16 A kötet első és második részében a tanulmányok az alábbi nagy témakörök szerint lettek felosztva: I. Kutatástörténet; II. Buddha-datálása az indiai kultúrtörténetben; III. Az indiai hagyomány szerinti Buddha-kronológia kiértékelése; IV. A théraváda kronológia elterjedése és az ezzel kapcsolatos összefüggések; V. A későbbi indiai és tibeti buddhista hagyomány; VI. A közép-ázsiai hagyomány; VII. A kelet-ázsiai hagyomány; VIII. A „tengelykor” elmélet és Buddha datálása. Az egyes szekciók között természetesen elkerülhetetlen az átfedés, így a tanulmányok és a cikkek saját belátás szerint beleilleszthetők egyik vagy másik szekcióba. A második és a harmadik kötetben számos, a kutatástörténet szempontjából fontos, korábban megjelent tanulmány újranyomatát is megtaláljuk. A harmadik kötetben pedig Bechert igen hasznos, válogatott, másodlagos forrásokat tartalmazó bibliográfiája is olvasható, amely az 1995-ig a Buddha-datálással, a Buddha-kronológiával és a
A kötet számos cikke foglalkozik a legszigorúbb értelemben vett kronológiával és történelemmel, de vannak olyan tanulmányok is, amelyek különféle indiai (buddhista és nem buddhista, például puránikus), kelet-ázsiai (kínai, vietnami, koreai és japán), valamint közép-ázsiai (tokhár, ujgur, iráni, tibeti és mongol) eredetű munkák szemszögéből közelítik meg a témát. Megint más tanulmányok a nyelvtörténet felől közelítenek a Buddhadatálás problémájához, néhány tanulmányban pedig a korai indiai kultúrtörténeti fejlődésből levonható tanúságokról olvashatunk, amelyek mérvadóak lehetnek Buddha korára nézve. Voltak olyan kutatók, akik a Buddha és az Asóka között eltelt időszakban végbement releváns filozófiai fejlődés lehetséges időintervallumát vizsgálták. Nem utolsósorban pedig külön kiemelném a régészeti és a kultúrtörténeti megfigyeléseket, valamint a nem buddhista, elsősorban a görög források elemzésének eredményeit.

A szimpóziumon résztvevő valamennyi, a témával foglalkozó kutató számára világos volt, hogy a Buddha-datálás problémáját nem lehet lezárni, és az előadások és viták során egyértelművé vált az is, hogy a kutatók nem fognak és nem tudnak egy konkrét időpontban megállapodni.

Wojtilla Gyula megfogalmazásában „A konferencia remélt célja, tudniillik hogy megkérdőjelezhetetlen bizonyítékot találjanak Buddha pontos datálására, nem valósult meg; egyetlen módszer, egyetlen bizonyíték sem bizonyult teljesen meggyőzőnek". ${ }^{17}$

A nyugati kutatásban évszázadokon keresztül elfogadott és érvényben lévő ún. javított „hosszú kronológiának” mindössze két képviselöje akadt: Yamazaki, valamint Narain. A számos indiai kutató körében néha még a mai napig is, néhány nyugati indológus körében pedig egészen az 1930-as évekig használt és

történeti Buddha kérdésével kapcsolatban megjelent bibliográfiák listája.

17 Wojtilla 2014. 13. 
érvényben lévő ún. „nem javított hosszú kronológiának" viszont nem akadt képviselője a szimpóziumon.

Ugyanakkor megfigyelhető volt egy erőteljes súlyponteltolódás a Buddha-datálásban. Egyetértés mutatkozott a kutatók körében - Yamazaki és Narain kivételével - annak kapcsán, hogy Buddha halálát i. e. 480-nál későbbre kell tenni, az i. e. 420 és i. e. 350 közötti időszakra.

A megoldási javaslatok közül ki kell emelnünk Gombrich tanulmányát. ${ }^{18}$ A szerző a buddhista tanítóknak a Dípavanszában, a ceyloni buddhista egyháztörténetben ránk maradt évszámait, Upálitól kezdve egészen Mahindáig, újraértelmezve Buddha életét a széles körben elfogadott dátumoknál kereken 80 évvel későbbre teszi. Gombrich kifejti, hogy részben egyetért Bechert azon véleményével, mely szerint a Dípavanszában lévő információ arra vonatkozólag, hogy Asóka megkoronázására Buddha halála után 218 évvel került sor amelyet később a théraváda források, továbbá számos nyugati kutató is elfogadott és vallott - túl hosszú és idejétmúlt. Ugyanakkor óvatos és szkeptikus azzal kapcsolatban, hogy erre Buddha halála utána 100 évvel került volna sor. A szerző a második buddhista zsinatot 60 évvel Buddha halála után, i. e. 345-re datálja. Az időpont véleménye szerint azért is helyesnek látszik, mert a Maurja birodalomra sehol nem történik utalás a Vinaja-Pitakában és a négy Nikájában sem. Az Asóka megkoronozása és a harmadik zsinat között eltelt 18 évet pedig pontos adatnak véli. Gombrich véleménye szerint Buddha 136 évvel Asóka megkoronázása előtt halt meg, vagyis i. e. 404-ben. Ha a hibalehetőségekkel is számolunk, akkor azt mondhatjuk biztosan, hogy Buddha i. e. 411 és 399 között halt meg. ${ }^{19}$

Eggermont a Buddha halálával kapcsolatos legkésőbbi dátumot javasolta. Szerinte Buddha Asóka király megkoronázása után 28

\footnotetext{
18 Gombrich 1992. 237-259.

19 Gombrich 1992. 240-253.
}

évvel, tehát i. e. 261-ben halt meg. ${ }^{20}$ Elmélete azonban nem talált támogatásra.

Vezető japán buddhológusok már korábban is az i. e. 390 és 368 közötti időintervallumot képviselték és tartották elfogadhatónak. A szimpózium egyetlen japán képviselöje kivételével senki sem tett konkrét és pontos javaslatot Buddha halálára a fent említett időintervallumon belül. A kivétel Nakamura volt, aki Buddha halálát az Asóka megkoronázása előtti 116. évre tette. ${ }^{21}$ A szintén japán Hirakawa mélyreható tanulmányában elsősorban a buddhizmus Indián belüli földrajzi elterjedését, valamint a buddhista szangha Buddha halála és Asóka uralkodása közötti feljődését elemezte, és arra a következtetésre jutott, hogy az elmélet, mely szerint Buddha halála Asóka előtt 100 évvel következett be, elfogadott a buddhisták körében Indiában, és a szangha fejlődését vizsgálva is erre az eredményre jutunk. A szerző meg van győződve arról, hogy a buddhista egyházon belüli fejlődés, amely Buddha halála és Asóka megkoronázása között zajlott le, egy évszázad alatt végbemehetett. Felhívta a figyelmet arra is, hogy a kronológiai adatok pusztán évszázadban történő megadása nagyon is jellemző volt a buddhista szövegekben. Jelen esetben az egy évszázad nem pontosan egy évszázadot jelent, hanem sokkal inkább azt, hogy az esemény óta egy évszázad telt el. ${ }^{22}$

\section{A rövid kronológiát igazoló tényezők, érvelések és bizonyítékok}

A Buddha halálára vonatkozó, kb. i. e. 420 és i. e. 350 közötti időintervallum mellett elsősorban a régészeti és a kultúrtörténeti megfigyelésekből nyert közvetett bizonyítékokkal lehet érvelni. Härtel véleménye szerint a régészeti ásatások nem támasztják alá, hogy valamennyi olyan város, amelyben Buddha a

\footnotetext{
20 Eggermont 1991. 237-251.

21 Nakamura 1991. 296-299.

22 Hirakawa 1991. 252-295.
} 
hagyomány szerint élt, vagy amelyet meglátogatott, már az i. e. 6. században létezett. A szerző szilárd meggyőződése, hogy az északi fekete fényezett kerámiát ${ }^{23}$ későbbre kell datálni, vagyis az i. e. 5. század jelölhető meg mint terminus ad quem. Ennek megfelelően a Buddha-datálással kapcsolatos i.e. 5-4. század valószínűbbnek látszik. ${ }^{24}$ Hasonló véleményen van Erdösy is, aki szerint a modern kori régészeti vizsgálatok sokkal inkább megegyeznek a mostanában a kutatók körében javasolt és elfogadott ún. „rövid kronológiával” (kb. i. e. 358-378), amely szinte valamennyi régészeti feltételezéssel is sokkal inkább összeegyeztethető, mint a hagyományos ún. „hosszú kronológia”. ${ }^{25}$ Ezen az állásponton van Sarao is, aki a Buddha-kori városok régészeti emlékeit elemezve kifejti, hogy a legtöbb kutató ma az i. e. 400 körüli időpontot fogadja el, de hozzáteszi, hogy a Buddha-datálással kapcsolatos viták nem zárultak le teljesen. ${ }^{26}$

Természetesen nem mindenki ért egyet ezzel a régészeti állásfoglalással. Az indiai Krishna Deva szerint valamennyi korai buddhista város alsóbb rétegeiben találtak ugyan északi fekete fényezett kerámiát, ám ennek megjelenése szerinte az i. e. 6. századra tehető, ennélfogva nem zárható ki az ún. „javított hosszú kronológia". ${ }^{27} \mathrm{Az}$ északi fekete fényezett kerámia i. e. 6. századra történő datálását vallja Sinha is, aki szerint ilyen kerámiatípust nagy számban és jó minőségben számos a Maurják előttről származó városban találtak. ${ }^{28}$

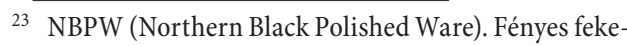
te színű, Észak- és Közép-India vaskori civizilációjára jellemző áru, többnyire korongolt tálak, csészék, edények. Jellemzően a Gangesz-völgyi városi civilizációval hozzák összefüggésbe. Az északi fekete fényezett kerámiával fémjelzett indiai kultúra ideje nagyjából két nagyobb szakaszra bontható: az i. e. 500-300 és az i .e. 300-100-ig terjedő időszakokra.

24 HärTEL 1991. 61-89.

25 ERdösy 1995. 99-122.

26 SARAo 2010. 6-16.

27 DEva 2003. 1-7.

28 SinHA 2003. 79-95.
Kulke tanulmányában - Ghoshra hivatkozva - azt írja, hogy az i. e. 5. századi városok, városi elemek megjelenése a Gangesz-völgyben nem utal olyan nagyfokú és kiemelkedő városiasodásra, mint amilyennek azt sokáig a korai buddhista források tanulmányozása alapján feltételezték. A városi fejlődésben olyan meghatározó tényezők, mint a várostervezés, a városok megerősítése, a monumentális építkezés és a tégla használata nem volt jelen a Gangeszvölgyben az i. e. 4. század előtt. Az észak-indiai korai várostörténetre utaló régészeti anyag sokkal inkább az ún. „rövid kronológiát” támasztja alá. ${ }^{29}$ Kulke elméletével szemben Sinha azonban azt veti fel, hogy az égetett téglából és kőből készült nagyszabású épületek hiánya nem utal feltétlenül az i. e. 3. század előtti monumentális építkezések hiányára is. Az épületek ugyanis valószínűleg agyagtéglából épültek, amit fából készült részek egészítettek ki, ezeknek viszont romlandó természetüknél fogva vagy nem maradt nyomuk, vagy emberi rongálásnak estek áldozatul, vagy érintetlenül és észrevétlenül maradtak a régészek szeme előtt, ami elsősorban annak köszönhető, hogy a térségben sok helyen még mindig nem végezték el a szükséges teljes körü régészeti ásatásokat. ${ }^{30}$

Kultúrtörténeti szempontból fontos von Simson állásfoglalása, aki tanulmányában arra figyelmeztet, hogy Buddha életének pontos datálása helyett érdemesebb lenne magára a buddhizmusra koncentrálni. Véleménye szerint a jól kiépített, szervezettel rendelkező buddhizmus kialakulásának feltétele egyrészt az elegendő élelmiszertöbblet volt, amelyet a vaseszközök alkalmazásával végrehajtott erdőirtások tettek lehetővé, másrészt a kereskedőkből, orvosokból és jómódú társadalmi elemekből álló városi központok jelenléte. ${ }^{31}$

29 KulKe 1991. 100-107.

30 Sinha 2003. 79-95.

31 Ezt az álláspontot képviselte korábban Ram Sharan Sharma, most is elfogadja Romila Thapar, és vitatja Richard Gombrich. 
Hogy ezek a feltételek pontosan mikor váltak adottá, arra csak az újabb és folyamatos régészeti ásatások eredményei segítségével lehet választ adni. Von Simson szerint Buddha halálának pontos datálása ugyan nem lehetséges, a legvalószínübbnek ugyanakkor egy későbbi időpont látszik. ${ }^{32}$

A nem buddhista, elsősorban görög forrásokból kiszűrhető, Buddha-datálásra utaló adatok elemzésével foglalkozó kutatók közül elsősorban Halbfass tanulmányát kell kiemelni. A szerző Megaszthenész Indika című munkájával, pontosabban annak Sztrabónnál fennmaradt részeivel foglalkozik. Az elemzés középpontjában elsősorban a Megaszthenésznél szereplő sarmanes (szkt. sramana) kifejezés áll. Halbfass arra a végkövetkeztetésre jut, hogy ebben a kifejezésben nincsen semmiféle, konkrétan a buddhizmusra utaló tartalom. Valószínűbb, hogy általános értelemben utal a világról lemondókra. Halbfass véleménye helytálló, amit Karttunen is alátámaszt megfigyelésével, mely szerint Asóka görög nyelvü feliratain a szó sramenai alakban ismert, s ez a szanszkrit sramanával együtt általában vándor szerzeteseket és ezek különböző csoportjait jelenti. ${ }^{33}$ A probléma tehát abból fakad, hogy egyértelmüen megfogalmazott, konkrétan Buddhára vagy a buddhizmusra történő utalás nem található Megaszthenésznél, illetve a Sztrabónnál fennmaradt töredékekben, de a többi Nagy Sándor-történetírónál sem. ${ }^{34}$ Megaszthenész tehát nyilvánvalóan hallgat Buddháról és a buddhizmusról annak ellenére, hogy az általa szerkesztett beszámoló szerint ő maga személyesen is járt Pátaliputrában, amely a buddhista források tanúsága szerint közismert volt buddhista jellegéről és emlékhelyeiről. Felvetődik tehát a kérdés, miként lehetséges az, hogy

32 Von Simson 1991. 90-99.

33 Karttunen 1997. 57-58.

34 Az első, egyértelműen Buddhára utaló nyugati forrás az i. u. 150-215-ben Alexandriai Kelemen munkájában olvasható, aki ugyanakkor egyértelmüen Megaszthenész munkájára hivatkozik.
Megaszthenész, miután járt Pátaliputrában, semmit nem hallott Buddha életéről és tanításáról? Egyes vélemények szerint Asóka kora előtt a buddhisták még nem játszottak olyan fontos szerepet, így Megaszthenész sem tett róluk külön említést. ${ }^{35} \mathrm{Ez}$ a felfogás azonban vitatható, mivel a buddhizmus egy élő, fejlődő és egyre inkább terjeszkedő vallás volt és élvezte az egyes uralkodók támogatását a szóban forgó két évszázadban India e részén. Felmerül ugyanakkor az a lehetőség is, hogy Megaszthenész hallott ugyan Buddháról és a buddhizmusról, de annyira jelentéktelennek tünt számára, hogy nem említette művében. Jóllehet a mü töredékes volta miatt nem lehetünk teljesen biztosak abban, hogy nem tett említést a buddhizmusról, az mindenesetre elgondolkodtató, hogy a ránk maradt szövegben nincs buddhizmusra vonatkozó utalás. Halbfass érveléséből az derül ki, hogy egyik hipotézis sem teszi lehetővé egy pontos kronológia felállítását, a vallás alapítójának későbbi évszázadra történő helyezéséhez pedig még több, mérvadó bizonyítékra lenne szükség. Halbfass ugyanakkor azt feltételezi, hogy a buddhizmus Megaszthenész korában még nem rendelkezett mintegy két évszázados múlttal, ennélfogva az i. e. 4. század végén még nem is produkálhatott markáns emlékmüveket, hiszen új és fiatal vallás lévén hatása még nem volt látható, érzékelhető és értelmezhető, amikor a görög követ meglátogatta Pátaliputrát kb. i. e. 300-ban. ${ }^{36}$ A sarmanes/sramana kifejezéssel számos kutató foglalkozott. Az indiai Sinha szerint a kifejezés magába foglalta a buddhistákat is, tehát összefoglaló elnevezése a heterodox vallásúaknak: dzsaináknak, buddhistáknak. A bráhmanák és a sramanák voltak a két meghatározó és fontos vallási szekta a korban. Ennek megfelelően Megaszthenész is e két csoportját különítette el a filozófusoknak. ${ }^{37}$

A három konferenciakötetben vannak

\footnotetext{
35 Dihle 1984. 89-97.

36 HalbFass 1991. 197-208.

37 SINHA 2003. 79-95.
} 
olyan tanulmányok is, amelyeknek szerzői az idő elteltével, a kutatás előrehaladtával, az újabb eredmények és adatok birtokában megváltoztatták korábban vallott nézeteiket. Ilyen kutató Bareau, aki korábban a „javított hosszú kronológia" szószólója volt, a kötetben szereplő tanulmányában azonban már egye nesen elutasítja mind a „nem javított”, mind pedig a „javított hosszú kronológiát”, mert ezek, véleménye szerint, nem egyeztethetők össze a modern régészeti adatokkal és bizonyítékokkal. Ennek megfelelőn Buddha halálát i. e. 400 körülre teszi, a terminus ante quemet pedig i. e. $380-$ ra. $^{38}$

Fontos von Stietencron elmélete, aki a Puránákban lévő kronológiai adatokból kiindulva próbálta meghatározni azt, hogy mikor élt Buddha. ${ }^{39}$ Megítélése szerint két lehetséges módja van a számításnak, attól függően, hogy hány évig uralkodtak a Nandák, ugyanis ez az időszak eltérő hosszúságú a puránikus hagyományban. Az első számítás alapján i. e. 487/486-at kapunk, amely megfelel az ún. "javított ceyloni kronológiának". A második számítás alapján pedig i. e. 547/546-at, amely körülbelül megfelel az ún. „nem javított ceyloni kronológiának”. Von Stietencron megjegyzi, hogy ezekből a számításokból a pontos dátumot megállapítani nem lehet, ugyanakkor feltételezi, hogy a puránai kronológia már létezett azelőtt, hogy az Asóka által küldött első buddhista követek megérkeztek volna Ceylonra. Arra is felhívja a figyelmet, hogy noha elképzelhető, hogy a közvetlenül a Maurják előtti királyok uralkodási évei pontosan meghatározhatók, de minden, ennél korábbi időszakra vonatkozó évszám túlnyomórészt csak feltételezés.

$\mathrm{Az}$ ún. CFrövid kronológia” igazolására gyakran a Dípavanszában lévő két szöveghelyet hozzák fel bizonyítékként. ${ }^{40}$ Ezeken a szöveghelyeken, számos kutató érvelése szerint,

\footnotetext{
38 Bareau 1991. 211-221.

39 Von Stietencron 1992. 141-181.

40 Dīp. 1. 24-27. és 5. 55-59.
}

egyértelmü utalást találunk a „rövid kronológiára”, míg az öszes többi hely a „hosszú kronológia” számításait látszik megerősíteni. ${ }^{41}$ Rhys Davids 1877-ben pubikálta először a Buddha-datálással kapcsolatos nézetét. Tanulmányában a Dípavanszában lévő kronológiai adatokat kritikusan értékelve Buddha halálát i. e. 400 és 423 közöttre helyezi: a legvalószínűbb időpontnak azi. e. 412-t sejti. ${ }^{42}$ A feltételezés tehát, hogy a Dípavanszában lévő adatok alapján pontosan datálhatjuk Buddha halálát, nem új. Bechert ezzel kapcsolatban kifejti, hogy később maga Rhys Davids is megjegyzi, hogy az általa korábban publikált számításával nem sikerült megállapítania Buddha halálának pontos idejét. Bechert hozzáteszi azt is, hogy Rhys Davids egyetlen későbbi cikkében sem talált utalást az általa 1877-ben publikált Buddhadatálásra. Ennek ellenére Ryhs Davids mégis többször kritikusan szólalt fel az ún. „hosszú kronológiael" ellen. ${ }^{43}$

$\mathrm{Az}$ említett két szöveghelyet Bechert is alaposan megvizsgálta. Jóllehet konkrét javas-

$41 \mathrm{Az}$ 1. 24-27.: Tulajdonképpen arról van szó, amint Buddha mondja, hogy négy hónappal az ö maháparinirvánája után megtartják az első gyűlést (zsinatot) ... 118 év múlva kerül sor a harmadik gyülésre (zsinatra), a buddhizmus terjesztése érdekében. Ekkor egy uralkodó fog uralkodni Jambudípa (India) fölött, nagy erényü, dicsőséges uralkodó, Dhammászóka (Asóka). Ennek a királynak lesz egy fia, az okos és intelligens Mahinda, Lankádípa (Srí Lanka) tanult térítője. Számos kutató úgy véli, hogy a hiányos és kipontozott szöveghelyen minden bizonnyal a második zsinatra történt utalás, amelyre Buddha halála után száz évvel került sor, a harmadik zsinatra pedig 118 évvel a második után. (Oldenberg 1879: 119.) Érdekes ugyanakkor, hogy az Asóka által összehívott feltételezett harmadik buddhista zsinatra sehol sem találunk említést vagy utalást Asóka rendeleteiben. Az 5. 55-59. rész Tissza Moggaliputta eljövetelelét írja meg 118 év múlva, és azt is megtudhatjuk, hogy ebben az időben egy Aszóka nevü királyi vezető fog uralkodni Pátaliputta fölött, egy igazságos herceg, aki a birodalmat felvirágoztatja. (Oldenberg 1879. 142.)

42 Davids 1877. (1992.) 401-421.

43 BeChert 1997. 5. 
lattal Buddha halálára vonatkozólag nem állt elő, ugyanakkor az i. e. 4. század első felét látta leginkább elfogadható időpontnak. Érvelésében kifejti, hogy a Dípavansza e két szövegrészlete bizonyosságul szolgál arra az ősi ceyloni hagyományra, amely szerint Buddha és Asóka megkoronázása között 100 év telt el. ${ }^{44}$ Egy másik helyen Bechert megjegyzi azt is, hogy már maga a tény is - tudnillik hogy egy és ugyanazon forrás kiértékelése különböző lehetséges és feltételezett megoldáshoz vezet - utal a Buddha-datálással kapcsolatban alkalmazott számítási módszerek gyengeségére. A szerző kiemeli azt is, hogy a Dípavanszában lévő adatok sajnos nem egyértelmüek, ennek megfelelően az adatok kiértékelése többismeretlenes egyenlethez vezet. Geiger és Frauwallner ráadásul már korábban bebizonyították, hogy a Dípavansza olyan különbözö források kompilációja, amelyek számos helyen egymással is ellentmondó adatokat tartalmaznak. Arra ugyanakkor már Kern, Thomas és Mendis is utaltak, hogy a Dipavanszában nyomai vannak az ún. „rövid kronológiának” is, amely a legrégebbi buddhista kronológia hagyományára utal. ${ }^{45}$ Más kutatók véleménye szerint ugyanakkor nem szabad figyelmen kívül hagyni azt a tényt, hogy a Dípavansza 5. fejezetében lévő kronológai spekulációt egyetlen más forrás sem támasztja alá még a legkisebb mértékben sem. A Dipavansza feltételezett szerkesztésének és Buddha feltételezett halálának időpontja között legalább fél évezred a különbség. Valószínűsíthető, hogy egy utókanonikus forrásról van szó.

\section{A hosszú kronológia képviselői}

A hedemündeni konferencián elért eredményeket azonban nem minden kutató fogadja el. 2003-ban jelentette meg első ízben Narain könyvét, amely tulajdonképpen a

\footnotetext{
44 BECHERT 1991. 329-343.

45 BeChert 1997. 5-6.
}

hedemündeni konferencia előadásait tartalmazó, Bechert-féle kötetre készült válaszkötet. A könyvben lévő pubikációk szerzőinek nagy része a „javított hosszú kronológia” mellett érvel. ${ }^{46}$

Srivastava tanulmányában összegzést nyújt a Buddha-datálásról és a németországi konferencián elért eredményekről. A szerző erős kritikával illeti a szimpóziumot, amely egyedülálló volt ugyan a maga nemében, de sajnos egyetlen indiai kutató sem vett részt rajta. Ugyanakkor pozitívumként értékelte, hogy Narainnak a témával kapcsolatos cikke megjelent a konferenciakötet második részében. ${ }^{47}$ Srivastava szerint a szimpózium elsődleges célja az volt, hogy a résztvevők előadásaikkal felülvizsgálják a Buddha-datálással kapcsolatos korábbi elméleteket. Ezzel visszautasították az évszázadokig érvényben lévő ún. „javított hosszú kronológiát”, és helyette az ún. „rövid kronológiát" tartották inkább elfogadhatónak, amely az i. e. 4. század környékére helyezi Buddha halálát. Fontosnak tartotta kiemelni azt is, hogy a konferencia résztvevőinek nagyrészt az indiai történelmet európai szemszögből értelmezö, görög-központú gondolkodás jellemezte, amely a városiasodást és az államiság kialakulását Nagy Sándorhoz köti, annak ellenére, hogy ezek a folyamatok - a szerző véleménye szerint - a perzsa Dareioszhoz köthetők. Emellett hangsúlyozta a régészet fontosságát és Krishna Devara hivatkozva amellett érvelt, hogy az északi fekete fényezett kerámia az i. e. 6. században jött divatba. ${ }^{48}$ Tehát visz-

46 Narain 2003.

47 NARAIN 1992. 185-199.

48 Hasonló véleményen van Giovanni Verardi is, aki Srivastavára hivatkozva úgy véli, hogy a KözépsőGangesz völgye, akárcsak Buddha születési helye, Lumbiní és annak környéke már jóval Buddha születése előtt - függetlenül attól, hogy a „hosszú” vagy a „rövid kronológiát” vesszük alapul - lakott terület volt. Ez a tény ömagában tehát nem nem zárja ki a „hosszú kronológiát”, ugyanakkor hozzáfüzi azt is, hogy a buddhizmus felemelkedésével szorosan összefüggő gazdasági változás - a vas széles körü 
szautasította Härtel és Erdösy nézetét is, akik a szóban forgó kerámia megjelenésére egy későbbi időpontot javasoltak. Srivastava bírálta Hirakawa és általában a japán kutatók nézetét is, akiket a szerző véleménye szerint túlságosan befolyásol az északi buddhista hagyomány. Továbbá a japán kollégák véleménye a Buddhadatálással kapcsolatos „rövid kronológia” pontos évszámának meghatározásában megítélése szerint annyira megosztott, hogy nehéz bármelyiküknek is hitelt adni. Szót emelt Eggermont azon nézete ellen is, mely szerint a Mahávíra halála körülbelül i. e. 252-ben következett be, vagyis Asóka uralkodásának 15. évében. Ez azért sem lehetséges - véli Srivastava -, mert az képtelenség, hogy egy ilyen fontos esemény Asóka uralma alatt említés nélkül maradt, és sem a rendeletekben, sem más forrásokban nem rögzítették. ${ }^{49}$

A hedemündeni konferencia eredményeit bíráló kutatók közé tartozik Narain is, aki a Bechert-féle konferenciakötetben megjelent tanulmányában és később is az elsőként Bühler által 1877-ben publikált tézist vetette fel újra. A feltételezés szerint az Asóka-rendeletben lévő „256”-os szám Buddha halálának évére utal. Narain úgy véli, hogy az Ahraurában található Asóka-rendelet meggyőzően bizonyítja a „javított hosszú kronológiát”, amely a szektariánus buddhista hagyománytól - legyen az északi vagy déli - függetlenül kezelendő forrás. Ennek megfelelően Asóka uralkodási ideje is független a buddhista hagyománytól. ${ }^{50}$ Bechert

használata, a mezőgazdasági többlet - nem tehető az i. e. 5. századnál korábbra, ami pedig a „rövid kronológiát” támasztja alá. A szerző nem foglalállást a Buddha-datálás kérdésben, véleménye szerint a régészet jelenlegi állása alapján nem adható válasz, ehhez további feltárásokra van szükség. (VERARDI 2010. 19-39.)

49 Srivastava 2003. 105-111.

50 NARAin 2003. 51-61. Az MRE I. szóban forgó változatában - amelyet 1961-ben találtak meg - abban különbözik az összes többitől, hogy egyedül itt olvasható az utolsó mondat végén a „Buddha teste” kifejezés. Narain erre a kifejezésre és a rendeletben szereplő „256”-os számra hivatkozva próbált újra érvelése szerint számos kutató, így például Oldenberg vagy Senart, már közvetlenül Bühler tézisének a megjelenése után megkérdőjelezték, hogy a szóban forgó Asóka-rendeletben lévő „256”-os szám Buddha halálánakévére utalna. ${ }^{51}$

\section{Összefoglalás}

A témával kapcsolatban összefoglalóan elmondhatjuk, hogy a jelenleg elérhető források és az ezekből leszürhető adatok alapján konkrét évszámot nem, csak egy relatíve tág időkeretet tudunk felállítani a Buddha-datálással kapcsolatban. Ennek fö oka, hogy az indiaiak Nagy Sándor hadjárata előtt nem rögzítették pontosan az időpontokat, illetve csak hozzávetőleges időrendet állítottak fel. A hedemündeni konferencia és az ott elhangzott előadásokból készült háromkötetes Bechert-féle kiadvány, valamint az erre reagáló Narain-féle válaszkötet megjelenése óta, legjobb tudomásom szerint, nem jelent meg újabb, a témához érdemben hozzászóló tanulmány vagy könyv. Ennek megfelelően tehát Buddha születési évének és halálának datálása a mai napig rengeteg nyitott kérdést vet fel, még akkor is, ha a legfrissebb régészeti és kultúrtörténeti elemzések eredményei alapján a kutatók többsége a korábbi elméletekkel ellentétben Buddha halálának időpontját az i. e. 420 és 350 közötti időszakra helyezi. A pontosabb időmeghatározást azonban a kutatás jelenlegi állása nem teszi lehetővé.

A „rövid kronológia” hitelessége és elfogadása ellen a kutatók általában azzal érvelnek, hogy az éppúgy ellentmondásokkal teli, mint a ,javított hosszú kronológia”. Sem a „rövid”, sem pedig a „hosszú kronológia” nem szolgál megbízható és hiteles kronológiai adattal. Ugyanakkor, ha feladjuk a Buddha halálának i. e. 486/480 körüli dátumát, akkor az egész időrend borul. A „javított hosszú kronológia”

érvényt szerezni a „javított hosszú kronológiának”.

51 BeChert 1997. 8-9. 
tehát ellentmondásaival együtt is egy sokkal inkább müködő és elfogadható hipotézisnek látszik, mint a „rövid kronológia”.

\section{FELHASZNÁLT IRODALOM}

Bareau, A. (1991): Some Considerations Concerning the Problem Posed by the Date of the Buddha's Parinirvāna. In Bechert, H. (ed.): The Dating of the Historical Buddha. Vol. 1. Göttingen, Vandenhoeck \& Ruprecht. 211-221.

BARUA, B. M. (1947): The Year of Commencement of the Buddha Era. In Bechert, H. (ed.): The Dating of the Historical Buddha. 1992. Vol. 2. Göttingen, Vandenhoeck \& Ruprecht. 461-467.

BECHERT, H. (1982): The Date of the Buddha Reconsidered. Indologica Taurinensia 10.29-36.

Bechert, H. (1991): The Origin and the Spread of the Theravāda Chronology. In Bechert, H. (ed.): The Dating of the Historical Buddha. Vol. 1. Göttingen, Vandenhoeck \& Ruprecht. 329-343.

Bechert, H. (1991 / 1992 / 1997): The Dating of the Historical Buddha $=$ Die Datierung deshistorischen Buddha. I. II. III. Göttingen, Vandenhoeck \& Ruprecht.

Bechert, H. (1997): Einleitung: Stand der Diskussion acht Jahre nach dem Symposion. In Bechert, $\mathrm{H}$. (ed.): The Dating of the Historical Buddha. Vol. 3. Göttingen, Vandenhoeck \& Ruprecht. 5-10.

BüHLER, J. G. (1877): The Three New Edicts of Aśoka. Indian Antiquary 6. 149-160.

Davids, Rhys T. W. (1877): On the Ceylon Date of Gautama's Death. Repr. In Bechert, H. (ed.): The Dating of the Historical Buddha. Vol. 2. 1992. Göttingen, Vandenhoeck \& Ruprecht. 401-421.

Deva, K. (2003): The Antiquity of Sites Related to the Buddha. In Narain, A. K. (ed.): The Date of the Historical Śākyamuni Buddha. New Delhi, B. P. Publishing Corporation. 1-7.

Dinle, A. (1984): Antike und Orient: gesammelte Aufsätze. Heidelberg, Carl Winter Universitätsverlag.

Eggermont, P. H. L. (1991): The Year of Buddha's Mahāparinirvāna. In Bechert, H. (ed.): The Dating of the Historical Buddha. Vol. 1. Göttingen, Vandenhoeck \& Ruprecht. 237-251.

Erdösy, G. (1995): City States of North India and Pakistan at the Time of the Buddha. In Allchin,
F. R. (ed.): The Archaeology of Early Historic South Asia: The Emergence of Cities and States. Cambridge, Cambridge Univ. Press. 99-122.

Gombrich, R. (1992): Dating the Buddha: A Red Herring Revealed. In Bechert, H. (ed.): The Dating of the Historical Buddha. Vol. 2. Göttingen, Vandenhoeck \& Ruprecht. 237-259.

HalbFass, W. (1991): Early Indian References to the Greeks and the First Western References to Buddhism. In Bechert, H. (ed.): The Dating of the Historical Buddha. Vol. 1. Göttingen, Vandenhoeck \& Ruprecht. 197-208.

HÄRTEL, H. (1991): Archaeological Research on Ancient Buddhist Sites. In Bechert, H. (ed.): The Dating of the Historical Buddha. Vol. 1. Göttingen, Vandenhoeck \& Ruprecht. 61-89.

HirakaWA, A. (1991): An Evaluation of the Sources on the Date of the Buddha. In Bechert, H. (ed.): The Dating of the Historical Buddha. Vol. 1. Göttingen, Vandenhoeck \& Ruprecht. 252-295.

Hultzsch, E. (1913): Contributions to Singhalese Chronology. In Bechert, H. (ed.): The Dating of the Historical Buddha. Vol. 2. Göttingen, Vandenhoeck \& Ruprecht. 430-444.

Karttunen, K. (1997): India and the Hellenistic World. Helsinki, Finnish Oriental Society.

Kulke, H. (1991): Some Considerations on the Significance of Buddha's Date for the History of North India. In Bechert, H. (ed.): The Dating of the Historical Buddha. Vol. 1. Göttingen, Vandenhoeck \& Ruprecht. 100-107.

Mendis, G. C. (1947): The Chronology of the Early Pāli Chronicles of Ceylon. Repr. In Bechert, H. (ed.): The Dating of the Historical Buddha. Vol. 2. 1992. Göttingen, Vandenhoeck \& Ruprecht. 445-460.

Nakamura, H. (1991): A Glimpse into the Problem of the Date of the Buddha. In Bechert, H. (ed.): The Dating of the Historical Buddha. Vol. 1. Göttingen, Vandenhoeck \& Ruprecht. 296-299.

Narain, A. K. (1992): The Date of Gotama Buddha's Parinirvāṇa. In Bechert, H. (ed.): The Dating of the Historical Buddha. Vol. 2. Göttingen, Vandenhoeck \& Ruprecht. 185-199.

Narain, A. K. (2003): An Independent and Definitive Evidence on the Date of the Historical Saakyamuni Buddha. In Narain, A. K. (ed.): The Date of the Historical Śākyamuni Buddha. New Delhi, B. P. Publishing Corporation. 51-64.

SARAO, K.T.S. (2010): Urban Centres and Urbanization: As Reflected in the Pāli Vinaya and Sutta Pitakas. New Delhi, Munshiram Manoharlal Publ. 
SinHA, B. P. (2003): Magadha Chronology and Date of the Buddha. In Narain, A. K. (ed.): The Date of the Historical Śākyamuni Buddha. New Delhi, B. P. Publishing Corporation. 79-95.

SPeyer, J. S. (1899): Buddhas Todesjahr nach dem Avadānaśataka. Repr. In Bechert, H. (ed.): The Dating of the Historical Buddha. Vol. 2. 1992. Göttingen, Vandenhoeck \& Ruprecht. 422-426.

Srivastava, V.C. (2003): The Date of Historical Buddha and the Göttingen Conference: Some Observations. In Narain, A. K. (ed.): The Date of the Historical Śākyamuni Buddha. New Delhi, B. P. Publishing Corporation. 105-111.

Turnour, G. (1837): The Maháwanso. In Roman Characters. With the Translation Subjoined; and an Introductory Essay on Pàli Buddhistical Literature. In two Volumes. Ceylon, Cotta Church Mission Press.

Verardi, G. (2010): Buddha's Birth and Reassessment of the Archaeological Evidence. In Cueppers, C. Deeg, M. - Durt H. (eds.): The Birth of the Buddha. Proceedings of the Seminar held in Lumbini, Nepal, October 2004. Lumbini, Lumbini International Research Institute. 19-39.

Von Simson, G. (1991): Der zeitgeschichtliche Hintergrund der Entstehung des Buddhismus und seine Bedeutung für die Datierungsfrage. In Bechert, H. (ed.): The Dating of the Historical Buddha. Vol. 1. Göttingen, Vandenhoeck \& Ruprecht. 90-99.

Von Stietencron, H. (1992): Die purāṇischen Genealogien und das Datum Buddhas. In Bechert, $\mathrm{H}$. (ed.): The Dating of the Historical Buddha. Vol. 2. Göttingen, Vandenhoeck \& Ruprecht. 148-181. Wojtilla Gyula (2014): A Buddha élete és tanítása. In Szilágyi, Zsolt - Hidas, Gergely (szerk.): Buddhizmus. Budapest. Vallástudományi Könyvtár - L' Harmattan Kiadó 6. 9-23. 